\title{
Leishmanias of Neotropical \\ Porcupines: Leishmania hertigi deanei nov. subsp.
}

R. Lainson $(")$
J. J. Shaw (")

\begin{abstract}
A leishmanial parasite was isolated from 11 of 18 porcupines from the general area of Ponta de Pedras, Island of Marajó, Pará State, north Brazil. Two of the infected animals were identified as Coendou prehensilis (Linnaeus), and the other 9 are considered as a hitherto undescribed species of Coendou. The organism is clearly related to $\mathbf{L}$. hertigi Herrer, of the Panamanian porcupine C. rothschildi Thomas, but morphological, serological and biochemical differences necessitate taxonomic distinction. The Brazilian parasite is therefore named Leishmania hertigi deanei nov. subsp., in honour of Dr. Leonidas Deane who first recorded it in porcupines from Piaui, Brazil. Like $\mathbf{L}$. h. hertigi, L. h. deanei produces no visible pathological effects in its natural host. Scanty amastigotes are scattered, often singly, throughout the skin and in the viscera; usually they can be detected only after the in vitro culture of tissues in blood-agar medium, in which $\mathbf{L}$. h. deanei grows readily. Attempts to infect hamsters and a guinea-pig with amastigote and promastigote forms were unsuccessful. The sandfly vector of the parasite is unknown.
\end{abstract}

\section{INTRODUCTION}

Leishmania hertigi Herrer 1971 was tirst described in the Panamanian porcupine $\mathrm{Co}_{\mathrm{O}}$ endou rothschildi Thomas: it appears to be specific for this animal, in which it causes no apparent pathological effects. Amastigotes are scattered, in small numbers, throughout the upper dermis but they evoke no host-cell reaction. Parasites were also found in the spleen and liver.

Although scanty amastigotes were seen in smears prepared from skinsnips, most in. fections were detected by the culture of skin or viscera in a slightly modified Senekji's blood-agar medium (McConnell, 1963). Intradermal inoculation of promastigotes from these cultures into hamsters produced relatively short-term infections in which small numbers of parasites could be seen in smears from the site of inoculation for only a few weeks. They could be demonstrated for ionger periods by the culture of skin from the point of inoculation, on rare occasions up to one year later. No parasites were found elsewhere in the skin or viscera of the infected hamsters.

The incidence of infection in the Panamanian porcupines was very high, with $83(88 \%)$ of 94 specimens positive. The infection was considered to be of long duration and confirmed to be up to 30 months in one captive animal.

Herrer gave a new specific name to the parasite, Leishmania hertigi, on the grounds of its apparent host-specificity in nature, failure of iniection in hamsters to protect these animals against subsequent challenge with L. braziliensis panamensis, and the peculiar elongate nature of the amastigotes (Fig. 14). $\mathrm{He}$ measured and illustrated both promastigotes from culture, and amastigotes from smears of porcupine skin, but stressed only the importance of the latter in comparison with the morphology of other leishmanias. Biochemical studies on $L$. hertigi from Panama have confirmed its specific identity (Chance, et al., 1974; Gardener, et al., 1974). Lainson \& Shaw (1973) provisionaliy placed the organism in the $L$. braziliensis complex but later (Lainson, et al., 1977) removed it into a distinct group of its own, following observations on its behaviour in experimentally infected sandflies and its distinctive biological and biochemical characters.

Deane, et al., (1974) examined spleen smears from a porcupine which was shot in the Mata do Cafundó forest, Município of José

(") - Instituto Evandro Chagas da Fundação Serviços de Saúde Pública, Belém, Pará, Brazil. 
de Freitas, State of Piauí, Brazil. Amastigotes were seen, but the organism was unfortunately not isolated and other tissues were not examined. Later, these authors found similar parasites in liver smears from another porcupine, apparently of the same species, and from the same locality. The animal was tentatively identified as Coendou prehensilis prehensilis (Linnaeus): no parasites were detected in smears of the skin, spleen, lung, kidney or peripheral blood. Once again, no isolation of the parasite was made, but the authors regarded it "as a Leishmania proper to the porcupines". The amastigotes of the Brazilian parasite differed considerably from those of $\mathrm{Pa}$ namanian L. hertigi in their iarger size and rodshaped kinetoplast. Deane, et al., wisely refrained from assigning a name to the organism, pending the aquisition of more adequate material.

Over the past few years we examined a number of porcupines from two different areas of forest in Pará State, north Brazil, and isolated a Leishmania, in blood-agar culture, which appeared very similar to that encountered by Deane, et al. On two occasions the infected animals were identified as Coendou prehensilis, but most of the isolates were made from what appears to be a new species of Coendou (').

\section{Materials AND Methods}

Both of the $C$. prehensilis and 14 of the new species of Coendou came from the general area of Ponta de Pedras, Marajó Island, Pará. Two additional specimens of the latter were also obtained from Utinga forest, Belém, Parả.

Cultures in blood-agar medium (modified NNN) were made from biopsied skin from various parts of the body, usually from the nose, feet, ears and tail: also from the skin, liver and spleen from autopsied animals. The method of skin culture was similar to that of Herrer, et al., (1966), except that we dispensed with the overnight incubation of skin-snips in refrigerated antibiotics. After removal of the spines and hair, the bare skin was cleaned with warm soapy water, followed by a thorough swabbing with iodine in 70 per cent ethyl alcohol. Before this dried, it was removed with several washes of 70 per cent spirit and the skin finally swabbed with ether. Skinsnips from the cleaned areas were removed with a sterile scalpel and scissors, and introduced directly into the fiuid phase of the bloodagar slopes: the latter were prepared as follows.

To $1,000 \mathrm{ml}$ of distilled water was added 28 grammes of Oxoid Nutrient Agar (Code $\mathrm{CM}_{3}$ ): this was heated in a water-bath until dissolved and distributed into the culture tubes in $4.0 \mathrm{ml}$ amounts. The tubes were then autoclaved, removed to a water-bath at $56^{\circ} \mathrm{C}$, and sufficient defibrinated rabbits blood added to each to give a concentration of about 5 per cent. They were stoppered with rubber bungs and slanted to give the usual NNN slopes: when the blood-agar slopes were firm, $0.5 \mathrm{ml}$ of sterile saline $(0.9 \% \mathrm{w} / \mathrm{v})$ containing 500 i.u. penicillin G (cryst) and $500 \mu \mathrm{g}$ of streptomycin sulphate was added, to each tube, as the fluid phase. As much of the culture procedure as possible was carried out in a sterile cabinet. Cultures of the porcupine tissues were maintained at $24-26^{\circ} \mathrm{C}$ and examined at weekly intervals: they were discarded if negative after one month.

Impression smears were prepared from skin-snips, liver, spleen, lung and kidney. These were air-dried as quickly as possible, fixed with absolute methyl alcohol and stained for one hour in Giemsa's stain (30 drops to 15.0

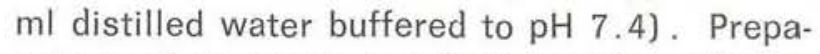
rations of promastigotes from positive cultures were made in a similar manner. Materiai for histology was fixed in 10 per cent formoi-saline, cut at $4.0 \mu \mathrm{m}$ and stained with haematoxylin and eosin. Amastigotes and promastigotes were measured by the photographic method we have previously described for the amastigotes of other leishmanias (Shaw \& Lainson, 1976): all measurements are given in $\mu \mathrm{m}$.

Triturates of skin and pooled liver and spleen were separately inoculated intrader-

(1) - Personal communication, Dr. C. O. Handley, Smithsonian Institution, Washington, D. C. See, also, Pine, R. H. (1973): we understand that a description of the animal is in press. 


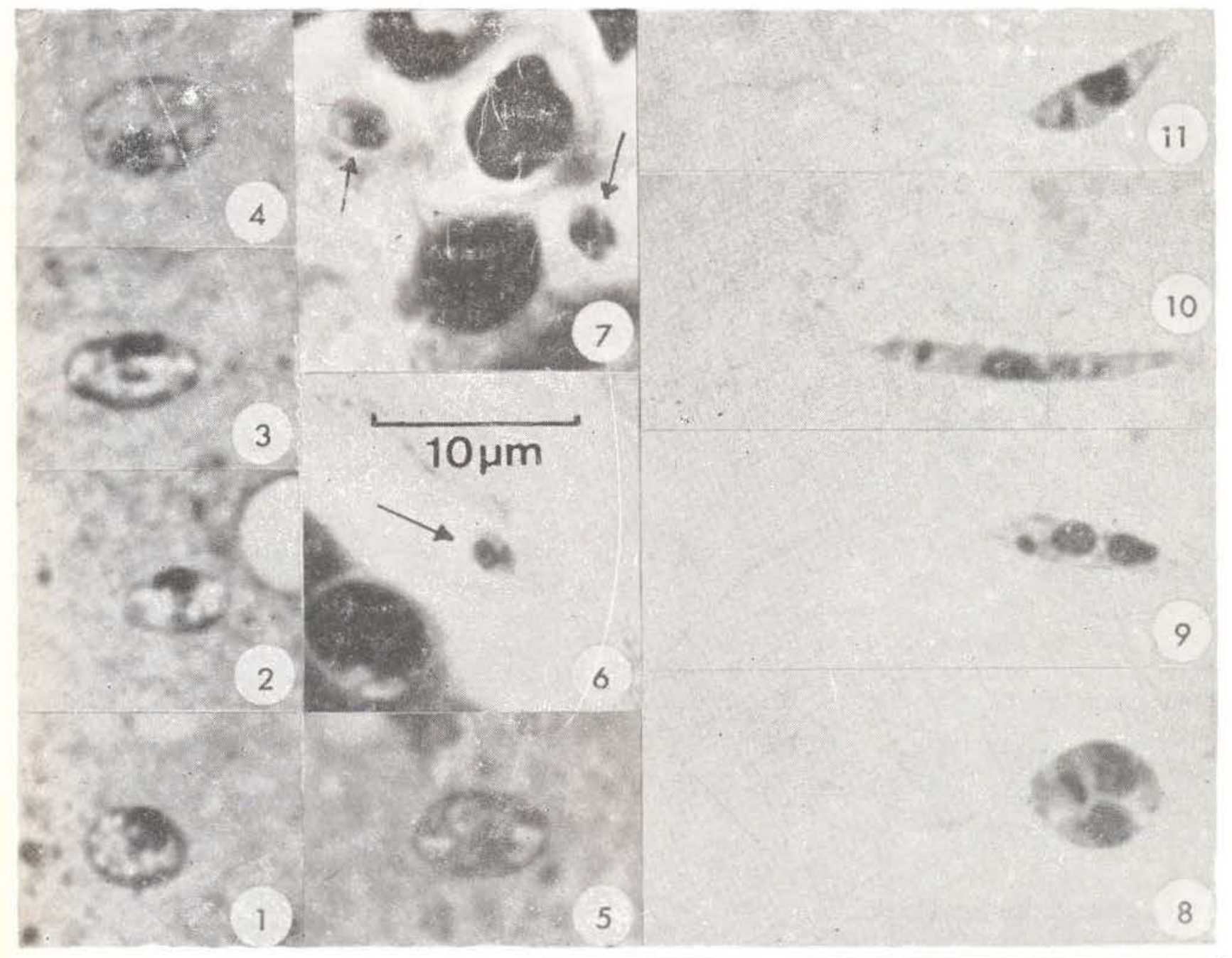

Figs. 1-11. Leismania hertigi deanei nov. subsp. 1-5, amastigotes in impression smears of liver and spleen of Coendou sp., from Pará State, north Brazil: Giemsa. 6-7, sections of skin from the tail of the same animal showing amastigotes scattered in the upper dermis: formol-salin fixation, haematoxylin \& eosin. 8-11, cultural forms; showing rounded and elongate dividing stages, and long and short promastigotes.

mally and intraperitoneally into hamsters in attempts to infect them with the porcupine parasite; and other hamsters and a single guinea-pig were inoculated with rich suspensions of promastigotes.

\section{RESULTS}

Promastigote flagellates grew luxuriantly in cultures from 11 of the 18 porcupines, including both of the $C$. prehensilis. In 8 instances the parasite was isolated only from the skin; in 2 cases from the skin and viscera; and in 1, only from the viscera. Scanty amastigotes (Figs
$1-5,13)$ were seen in the liver and spleen of one animal (Coendou nov. sp.): microscopic demonstration of amastigotes was otherwise limited to histological sections of the skin of the same animal (Figs. 6 \& 7). These showed extremely scanty, single parasites scattered throughout the upper dermis and usually lying in a smal! vacuole. In section the amastigotes appeared much smaller than those in the liver and spleen smears (Figs. 1-7), doubtless due to shrinkage in the fixed tissue and/or expansion of the flettened parasites in impression smears. A similar size difference in sections and smears was noted for L. hertigi of the Panamanian porcupine (Herrer, 1971). 
We were unable to determine the exact nature of the parasitized ceil, for all the amastigotes seen in smears were extracellular and no clear association of parasite and host celi was apparent in sections. On no occasion was the organism seen to provoke any host cellular reaction. The paucity of amastigotes in all tissues examined permitted measurement of only 12 examples, all from the liver and spleen smears of one animal.

We have noted morphological differences between this parasite and $L$. hertigi from Panama, the Brazilian organism being considerably larger: in addition there are significant serological and biochemical differences $\left.{ }^{2}\right)$. Some form of taxonomic distinction is thus warranted and, as the two leishmanias are cleariy closely related, we feel that separation is best made at subspecific level. The name Leishmania hertigi deanei nov. subsp., is given for the parasite from C. prehensilis, in Brazil, in honour of our old friend Leonidas Deane: that of the Panamanian porcupine, C. rothschildi, thus becomes $L$. hertigi hertigi Herrer. Type material is held in our collection of slides at the Institute Evandro Chagas, Belém.

Leishmania hertigi deanei nov. subsp.

MORPHOLOGY OF THE AMASTIGOTE: (Figs, 1-5, 13).

The parasite is ellipsoidal and ranges from $5.1 \times 3.1 \mu \mathrm{m}$ to $6.8 \times 4.5 \mu \mathrm{m}$, average $6.1 \times 3.7$ $\mu \mathrm{m}$. The cytoplasm stains a clear, bright blue and is markedly vacuolated. The nucleus is predominently oval to round in outline: it measures approximately $2.5 \mu \mathrm{m}$ in diameter and is usually placed close up against the cel! wall. The kinetoplast is oval to rod-shaped, frequently curved: it is sometimes so close to the nucleus that it becomes difficult to detect.

MORPHOLOGY OF THE PROMASTIGOTE: (Figs. 8-12) .

It is unfortunate that this description has to be based on promastigotes from in vitro culture, for in our experience with other leishmanias the cultural forms may differ consicerably from the various cieveiopmental stages seen in the sandfly vector.

live fiageilates from 6-14 day-oid cuitures snowed sucn a diversity of rorm that $i t$ is coubirul is average measurements or even a very large number would be very meanıngruı in a comparison with $L$. h. hertigi: the ract inat wuin rouraed and elongate division forms were Equainy curinion also compilcates the ue. scription. IVleasurements and disposicion oi the nucieus and kinetoplast are tairiy stabie characters, however, and illustrations and men. sural aata (lapie I) are therefore given for cu cultural rorms, rrom a 10 day-oid blood-agar culture.

body length and width of the smaiiest eiongate forms may be as iittle as $6.0 \times 2.0 \mu \mathrm{m}$, wicn a tree tiagelium of $11-16 \mu \mathrm{m}$ : larger pro. mastigotes reach up to $18.0 \times 2.5 \mu \mathrm{m}$, with the riagellum up to $24.0 \mu \mathrm{m}$ long. Most of the eiongate parasites taper gently to a rinely pointed posterior end and possess a more abruptiy pointed anterior: this imparts a somewhat "cigar-shaped" appearance. More rarely the anterior end may be rounded. The cytopiasm stains deiicately and may contain a variabie number of heavily stained, reddish granules. Position of the nucleus is variable; sometimes central, but most usually slightly more towards the anterior end of the fiagellate. It is most commonily ovoid or rounded, sometimes elongated and more irreguiar. The kinetoplast is conspicuous, oval to kicineyshaped, rarely rounded: it is situated about $1.5-3.0 \mu \mathrm{m}$ from the anterior end. The free flagellum is extremely variable in length, but many variations may be due to breakage in making the preparations. Elongate and rounded division stages are equally common, and bizarre forms may sometimes be found with three flagella or four nuclei.

HOST: Coendou prehensilis (Linnaeus) and Coendou sp. (nov. sp., Handley, et al., see previous footnote).

TYPe LOCALITY: Ponta de Pedras, Marajó Island, Pará, State, north Brazil.

(2) - Personal communication from Mr. S, L. Croft, Dr. M. L. Chance and Dr. L. F. Schnur, Liverpool School of Tropical Medicine. 
SITE AND TYPE OF INFECTION: throughout upper dermis, liver and spleen. Infection inapparent, with numbers of parasites frequently so low that they can be detected only after the culture of tissues in blood-agar medium. No visible pathology: absence of any host-cell re action associated with parasites, which are often limited to single amastigotes widely scattered in the tissue.

INFECTIVITY FOR LABORATORY ANIMALS: no detectaible infections have yet been produced in hamsters or the guinea-pig.

VECTOR: unknown. Presumably a phlebotomine sandfly.

TAXONOMY: Failure to establish either attached hindgut or foregut developmental stages in sandflies (Anon., 1967; Lainson, et al., 1977) and characteristic biochemical features (Chance, et al., 1974; Gardener, et al., 1974) precludes the inclusion of $L$. hertigi in either the $L$. braziliensis or L. mexicana complexes: it was thus removed to a group on its own (Lainson, et al., 1977). L. hertigi hertigi and L. hertigi deanei are differentiated by the morphology of the amastigotes, as seen in their respective porcupine hosts (present studies), serologically, and biochemically by electrophoretic mobility patterns of glucose phosphate isomerase and glucose-6-phosphate dehydrogenase (Croft. Schnur \& Chance, personal communication).

\section{DISCUSSION}

The average measurements of the amastigotes described by Deane, et al., (1974) in the porcupines from Piaui were $6.1 \times 3.4 \mu \mathrm{m}$ - so similar to our own measurements of $6.1 \times$ $3.7 \mu \mathrm{m}$ that there can be little doubt that these authors were also dealing with $L$. $h$. deanei. They described two other characteristics which agree with our own observations; namely the highiny vacuolated nature of the cytoplasm, and the elongated form of the kinetoplast, which has the form of a small curved rod.
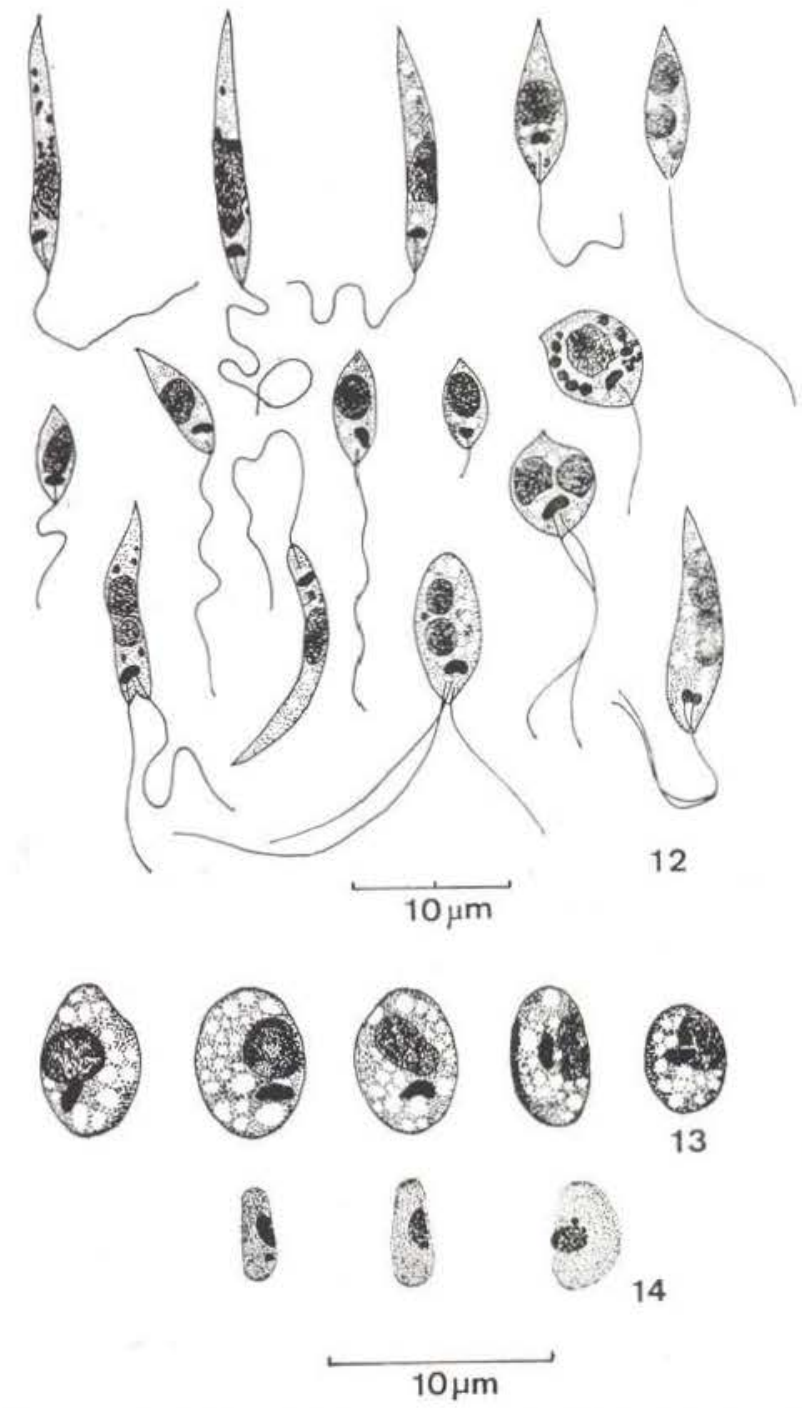

13

14

Figs. 12-13, Leishmania hertigi deanei nov. subsp. 12 , variety of dividing and non-divided promastigotes seen in a 10-day-old blood-agar culture. 13, amastigotes in liver and spleen smears of Coendou sp. Giemsa. Fig. 14. Leishmania hertigi hertigi: amastigotes in skin smears of Coendou rothschildi (reproduced, at same scale, from Herrer, 1971). Note much smaller size, lack of vacuoles in cytoplasm, and different form of kinetoplast

Amastigotes of $L$. h. deanei would thus appear to be morphologically distinct from those of L. h. hertigi, in their respective porcupine hosts. The latter parasite measures only from 3.5 to $4.8 \mu \mathrm{m} \times 1.2$ to $2.5 \mu \mathrm{m}$ and the kinetoplast is "frequently rounded" (Herrer, 1971). Furthermore, Herrer's illustrations show no evidence of the prominent vacuolation so typical of L. h. deanei. The morphological 
TABLE I. Measurements, in ${ }_{\mu} \mathrm{m}$, of 20 promastigotes of Leishmania hertigi deanei nov. subsp., from 10-day-old blood-agar cultures.

\begin{tabular}{|c|c|c|c|c|c|c|c|c|c|}
\hline & $\begin{array}{c}\text { Body } \\
\text { Length }\end{array}$ & $\begin{array}{l}\text { Body } \\
\text { Width }\end{array}$ & & $\mathbf{K}$ & Flgm & $\mathbf{K}-\mathbf{A}$ & $\mathbf{P}-\mathbf{N}$ & $A-N$ & $\begin{array}{c}\text { Diam } \\
\text { Nucleus }\end{array}$ \\
\hline 1. & 6.0 & 2.0 & 1.0 & $\times 0.75$ & 11.0 & 1.5 & 3.0 & 3.0 & $2.5 \times 1.5$ \\
\hline 2. & 6.5 & 2.0 & 1.0 & $\mathrm{x} 0.5$ & 16.0 & 1.75 & 3.0 & 3.5 & $2.5 \times 1.5$ \\
\hline 3 & 7.0 & 6.0 & 1.5 & $\mathrm{x} 1.0$ & 7.0 & 2.0 & 3.0 & 4.0 & $2.75 \times 2.5$ \\
\hline 4. & 7.5 & 2.5 & 1.0 & $\times 0.5$ & 17.5 & 2.0 & 3.5 & 4.0 & $2.5 \times 2.0$ \\
\hline 5. & 8.0 & 2.5 & 1.0 & x 0.5 & 15.5 & 1.5 & 4.0 & 4.0 & $2.5 \times 2.0$ \\
\hline 6. & 8.5 & 2.5 & 1.0 & x 0.5 & 15.0 & 2.0 & 4.0 & 4.5 & $2.5 \times 2.5$ \\
\hline 7. & 10.0 & 2.5 & 1.5 & $\times 0.75$ & 20.0 & 1.5 & 6.0 & 4.0 & $4.0 \times 2.0$ \\
\hline 8. & 10.5 & 3.0 & 1.0 & $\mathrm{x} 0.5$ & 12.5 & 3.0 & 4.5 & 6.0 & $3.0 \times 3.0$ \\
\hline 9. & 11.0 & 2.0 & 1.0 & $\times 0.5$ & 19.0 & 1.5 & 7.5 & 3.5 & $2.5 \times 1.5$ \\
\hline 10. & 12.0 & 1.5 & 1.0 & $\times 0.75$ & 13.0 & 2.5 & 7.0 & 5.0 & $3.0 \times 1.5$ \\
\hline 11. & 12.0 & 1.5 & 1.0 & $\times 0.75$ & 12.0 & 2.0 & 7.0 & 5.0 & $2.5 \times 1.5$ \\
\hline 12. & 12.0 & 2.0 & 1.0 & $\times 0.5$ & 19.0 & 2.0 & 6.5 & 5.5 & $5.0 \times 2.0$ \\
\hline 13. & 13.0 & 2.0 & 1.0 & $\mathrm{x} 0.5$ & 13.0 & 2.5 & 7.0 & 6.0 & $3.0 \times 1.5$ \\
\hline 14. & 13.0 & 2.0 & 0.75 & $\times 0.5$ & 15.0 & 1.5 & 8.5 & 4.5 & $3.0 \times 1.75$ \\
\hline 15. & 13.0 & 2.5 & 1.5 & $\times 0.5$ & 22.5 & 2.5 & 6.0 & 7.0 & $4.0 \times 2.0$ \\
\hline 16. & 14.0 & 2.0 & 1.0 & $\times 0.75$ & 10.0 & 3.5 & 8.0 & 6.0 & $3.0 \times 2.0$ \\
\hline 17. & 15.5 & 2.0 & 1.0 & $\times 0.75$ & 15.0 & 2.5 & 90 & 6.5 & $3.5 \times 1.5$ \\
\hline 18. & 17.0 & 1.5 & 1.0 & $\times 0.75$ & 19.0 & 2.0 & 11.0 & 6.0 & $4.0 \times 1.5$ \\
\hline 19 & 17.0 & 2.0 & 1.0 & $\times 0.75$ & 15.0 & 2.5 & 11.0 & 6.0 & $3.5 \times 1.5$ \\
\hline 20. & 18.0 & 2.0 & 1.25 & $5 \times 0.5$ & 24.0 & 2.5 & 11.0 & 7.0 & $6.5 \times 1.5$ \\
\hline
\end{tabular}

$\mathrm{K}=$ kinetoplast; $\mathrm{Figm}=$ flagellum; $\mathrm{K}-\mathrm{A}=$ distance from kinetoplast to anterior end of body; P- $\mathrm{N}=$ distance from pos$\mathrm{K}=$ kinetoplast; $\mathrm{Figm}=$ flagellum; $\mathrm{K}-\mathrm{A}=$ distance from anterior end of body to middle of nucleus. 
differences of the two parasites are shown in Figs. $13 \& 14$.

The vectors of both subspecies of $L$. hertigi remain unknown. Workers at the Gorgas Memorial Laboratory in Panama found $L . h$. hertigi to develop very poorly in the local sandfly species Lutzomyia sanguinaria and Lu. gomezi (Anon, 1967), and Lainson et al., (1977) had no greater success with $L$. h. deanei in $L u$. longipalpis.

\section{ACKNOWLEDGEMENTS}

These studies were carried out under the auspices of the Wellcome Trust, London, and the Instituto Evandro Chagas da Fundação Serviços de Saúde Pública, Belém, Pará, Brazil. We are particularly indebted to Roberto Daibes Naiff and Maricleide Dantas de Farias for their skilled technical assistance; to $\mathrm{Mr} \mathrm{S}$. L. Croft, Dr. M. L. Chance and Dr. L. F. Schnur of the Liverpool School of Tropical Medicine for making available to us their unpublished results of serological and biochemical studies on $L$. $h$. hertigi and L. h. deanei; and to Dr. C. O. Handley of the Smithsonian Institution, Washington, D. C., for identification of the porcupines studied in this work.

\section{Sumário}

Isolamento de Leishmania foi obtido de $11 \mathrm{em}$ 18 porcos-espinhos da área geral de Ponta de Pedras, ilha do Marajó, Estado do Pará, Norte do Brasil. Dois dos animais infectados eram Coendou prehensilis (Linnaeus), e os outros 9 foram considerados como sendo uma espécie ainda não descrita de Coendou.

O parasita está claramente relacionado à L. hertigi Herrer, do porco-espinho do Panamá, C. rothschildi Thomas, porém existem diferenças morfológicas, sorológicas e bioquímicas, que tornam necessária a distinção taxonomica desse organismo. Desta maneira, o novo parasita encontrado no Brasil foi chamado Leishmania hertigi deanei nov. subsp., em homenagem ao Dr. Leonidas Deane, que foi o primeiro a registrá-lo em porco-espinhos do Estado do Piauí, Brasil.

Da mesma maneira que a $\mathbf{L}$. hertigi hertigi, a L. hertigi deanei não produz efeitos patológicos visiveis em seu hospedeiro natural. Raros amastigotos, freqüentemente isolados, são encontrados na pele e nas visceras. Usualmente sāo detectados apenas in vitro, por cultivo de tecidos em meio de agar-sangue, nos quais a L. h. deanei apresenta crescimento rápido.
Tentativas para infectar hamsters e cobaias com iorma de amastigotos e de promastigotos não tiveram êxito.

O flebótomo vetor do parasita ainda é desconhecido.

\section{LTTERATIURE CITED}

ANON.,

1967 - 38th Annual Report of the Work and Operations of the Gorgas Memorial Laboratory, Fiscal Year 1966. U.S. Govt., Printing Office, Washington.

Chance, M.L.; Peters, W. \& Shchory, L.

1974 - Biochemical taxonomy of Leishmania I. Observations on DNA. Ann. trop. Med. Parasitol., 68, 307-316.

Deane, L.M.; Silya, J.E. \& Figueiredo, P.Z.

1974 - Leishmaniae in the viscera of porcupines from the State of Piaui, Brazil. Rev. Inst. Med. trop. São Paulo, 16, 68-69.

Gardener, P.J.; Chance, M.L. \& Peters, W.

1974 - Biochemical taxonomy of Leishmania II. Electrophoretic variation of malate dehydrogenase. Ann. trop. Med. Parasitol., $68,317-325$.

HERRER, A.

1971 - Leishmania hertigi sp. n. from the tropical porcupine, Coendou rothschildi Thomas. J. Parasitol., 57, 626-629.

Herrer, A.; ThAtCher, V.E. \& Johnson, C.

1966 - Natural infections of Leishmania and trypanosomes demonstrated by skin culture. J. Parasitol., 52, 954-957.

Lainson, R, \& Shaw, J.J.

1973 - Leishmanias and leishmaniasis of the New World, with particular reference to Brazil. Bull. Pan. Amer. Hith. Org., 7 (4), 1-19.

Lainson, R.; Ward, R.D. \& Shaw, J.J.

1977 - Leishmania in phlebotomid sandflies. Importance of hindgut development in distinguishing parasites of the L. mexicana and $\mathbf{L}$. braziliensis complexes. Proc. Roy. Soc., (B), in press.

MCCONNELL, E.

1963 - Leptomonads of wild-caught Panamanian Phlebotomus: culture and animal inoculation. Exp. Parasitol., 14, 123-128.

PINE, R.H.

1973 - Mammals (exclusive of bats) of Belém, Pará, Brazil. Acta Amazonica, 3(2): 47-79.

Shaw, J.J. \& Lanson, R.

1976 - Leishmaniasis in Brazil: XI. Observations on the morphology of Leishmania of the braziliensis and mexicana complexes. J. trop. Med. \& Hyg., 79 : 9-13. 